\title{
PERANCANGAN E-MARKETING UMKM KERAJINAN TAS
}

\author{
Nanik Susanti \\ Fakultas Teknik, Program Studi Sistem Informasi \\ Universitas Muria Kudus \\ Email: nanik.susanti@umk.ac.id
}

\begin{abstract}
ABSTRAK
Perkembangan teknologi, dunia digital dan internet berdampak kuat pada dunia pemasaran. Diciptakannya teknologi e-marketing sebagai salah satu strategi pemasaran yang mampu menjangkau jaringan masyarakat luas. Perancangan e-marketing dalam penelitian ini ditujukan kepada usaha mikro, kecil dan menengah pengrajin tas yang tergabung dalam KUB Valya Bags di Desa Gulang. Permasalahan yang dihadapi oleh para pengrajin adalah minimnya strategi pengembangan usaha, masih menggunakan sistem traditional marketing. Jangkauan pasar sempit, Keterbatasan media promosi serta keluhan calon pembeli yang merasa kesulitan untuk mengetahui detail produk tas. Metode penelitian yang dilakukan dengan menganalisa kebutuhan yang dapat menghasilkan pemodelan sistem pemasaran dengan menggunakan perancangan sistem UML. Penelitian ini menghasilkan sebuah analisa dan perancangan $e$ marketing bagi UMKM pengrajin Tas di Desa Gulang yang diharapkan mampu menjangkau pasar yang lebih luas, jumlah konsumen meningkat serta dapat menjalin hubungan interaksi penjual dan pembeli tanpa dibatasi ruang dan waktu yang pada akhirnya dapat meningkatkan perekonomian masyarakat khusunya para pengrajin tas. Sistem yang dibangun meghasilkan aplikasi website untuk pemasaran produk tas yang diproduksi oleh KUB Valya Bags. Aplikasi website dapat diakses melalui URL http://www.valyabags.online.
\end{abstract}

Kata kunci: strategi pemasaran, e-marketing, kerajinan tas.

\begin{abstract}
Technological developments, digital world and internet have a powerful impact on the marketing world. The creation of e-marketing technology as one marketing strategy that is able to reach the wider community network. The design of e-marketing in this research is aimed at micro, small and medium enterprises of handicraft merchants incorporated in KUB Valya Bags in Gulang Village. The problem faced by the craftsmen is the lack of business development strategy, still using the traditional marketing system. Narrow market reach, Limitations of promotional media and complaints of potential buyers who find it difficult to find out the product details of the bag. The research method is done by analyzing the need that can generate the modeling of marketing system by using UML system design. This research resulted in an analysis and design of e-marketing for UMKM handicraftsmen Bags in Gulang Village which is expected to reach a wider market, the number of consumers increases and can establish interaction between sellers and buyers without limited space and time which ultimately can improve the economy of the community especially bag craftsmen. The system built produced website application for bag product marketing produced by KUB Valya Bags. Website applications can be accessed via URL http://www.valyabags.online
\end{abstract}

Keywords: marketing strategy, e-marketing, handicraft bags.

\section{PENDAHULUAN}

Perkembangan teknologi, dunia digital serta internet memberikan imbas yang kuat pada dunia pemasaran. Sistem pemasaran yang semula tradisional(offline) sekarang beralih ke digital(online). Emarketing merupakan strategi pemasaran yang memanfaatkan teknologi internet dengan website sebagai mediatornya. Konsep e-marketing sebenarnya hampir sama dengan pemasaran secara tradisional, yang membedakan adalah medianya[1]. Jika e-marketing sudah memanfaatkan media online bisa berupa website, jejaring soial, email, blog dan aplikasi yang lainya. Dengan e-marketing mampu menjangkau pasar yang lebih luas dan menjaring pelanggan lebih banyak Menurut[2] e-marketing bisa diartikan sebagai bagian dari e-commerce yang merupakan aktivitas perusahaan dalam mengelola kegiatan komunikasi, melakukan kegiatan promosi dan melakukan kegiatan jual beli produk baik barang maupun jasa melalui internet. Sistem pemasaran yang menggunakan e-marketing dapat memudahkan client memperoleh 
informasi produk dan jasa secara cepat dan efisien, sehingga memberikan kepuasan kepada pelanggan dengan menciptakan dan mempertahankan hubungan yang baik dengan client.[3] Pemakaian internet menjadi sarana yang ampuh dalam melakukan aktivitas pemasaran produk dan jasa misalkan melalui website.kegiatan ini disebut sebagai kegiatan e-marketing yang dapat membantu memenuhi kebutuhan perusahaan atau organisasi[4]. Kegiatan bisnis yang memanfaatkan teknologi $e$-marketing memiliki target bisnis yang jelas untuk membidik lebih banyak konsumen[5].

Kerajinan tangan sudah menjadi alternatif dari berbagai pilihan pola hidup dan menjadikanya sebuah usaha yang menjanjikan. Produksi Kerajinan yang memiliki ciri khas dan kwalitas produksi yang baik maтри meningkatkan gairah pangsa pasar. Salah satunya adalah kerajinan tas dengan berbagai model dan jenis tas yang dihasilkan oleh sebagian besar masyarakat Desa Gulang. Kerajinan tas menjadi produk unggulan desa yang dapat meningkatkan perekonomian masyarakat desa Gulang.

Permasalahan yang dihadapi adalah minimnya strategi pengembangan usaha. Kebanyakan pengrajin atau KUB masih mengandalkan penjualan secara tradisional. sistem pemasaran produk masih manual, masih mengandalkan media komunikasi interaksi secara langsung dengan konsumen dan masih berpusat pada lokasi tempat tertentu seperti datang langsung ke tempat pengrajin atau ketika ada pameran. Permasalahan lain calon pembeli seringkali kesulitan untuk mengakses berbagai kebutuhan informasi tentang produk, informasi tentang harga terbaru, serta media promosi yang terbatas hanya sedikit yang menggunakan teknologi informasi khususnya website untuk melakukan promosi. Dari permasalahan yang ada masih dibutuhkan strategi pemasaran berbasis online yang dapat menjangkau pasar yang lebih luas mempermudah proses promosi dan penjualan hasil produk pengrajin.

\section{METODOLOGI PENELITIAN}

\subsection{Metode Pengembangan Sistem}

Perancangan digital marketing dilakukan dengan menerapkan metode pengembangan sistem air terjun (waterfall). Pemodelan waterfall merupakan pendekatan metode klasik populer yang sering digunakan oleh pengembang sistem karena dianggap lebih mudah. Tahapannya meliputi communication, planning, modeling, dan deployment.

\subsection{Metode Pengumpulan Data}

Untuk memperoleh data yang diperlukan lebih akurat, model pengumpulan data dilakukan dengan cara sebagai berikut:

a. Observasi, merupakan kegiatan pengamatan dan pencatatan aktifitas pemasaran yang dilakukan oleh KUB valya bag's sehingga dapat diketahui hambatan dan permasalahan yang dihadapi.

b. Studi Kepustakaan, yaitu mencari referensi yang ada dalam buku, literatur, jurnal, catatan, dll yang mendukung penyusunan laporan penelitian.

c. Wawancara, melakukan kegiatan tanya jawab dengan pelaku usaha atau pengrajin tas yang tergabung di KUB Valya bag's.

d. Dokumentasi, melakukan pengarsipan kegiatan pengrajin tas yang sudah dilakukan.

\subsection{Analisa Kebutuhan Sistem}

Untuk membuat atau merancang digital marketing ini data-data yang dibutuhkan diantaranya:

a. Data Kategori Produk

b. Data Produk

c. Data Pembeli

d. Data Jasa Pengiriman

Berdasarkan pengelompokkan data diatas, diharapkan menghasilkan perancangan digital marketing yang dapat mengelola kegiatan sebagai berikut:

a. Kelola informasi katalog produk

b. Kelola Pemesanan

c. Kelola Registrasi pembeli

d. Kelola Konfirmasi Pembayaran

e. Kelola Pengirirman 


\subsection{Perancangan Sistem}

Untuk mengilustrasikan aktivitas sistem, pemodelan proses dalam perancangan sistem yang digunakan adalah model UML (Unified Modeling Language). Pemodelan proses UML merupakan sistem arsitektur yang bekerja dengan Object Oriented Arcitechture Design (OOAD) . Dimana OOAD ini didukung dengan satu bahasa yang konsisten dalam menentukan, mengviisualisasikan, mengkontruksi, dan mendokumentasikan artifact yang terdapat dalam sistem software [4].

\subsection{Kerangka Pikir Penelitian}

Kerangka pikir yang ditunjukkan pada gambar 1 memberikan gambaran serta pemaparan alur penelitian e-marketing UMKM kerajinan tas.

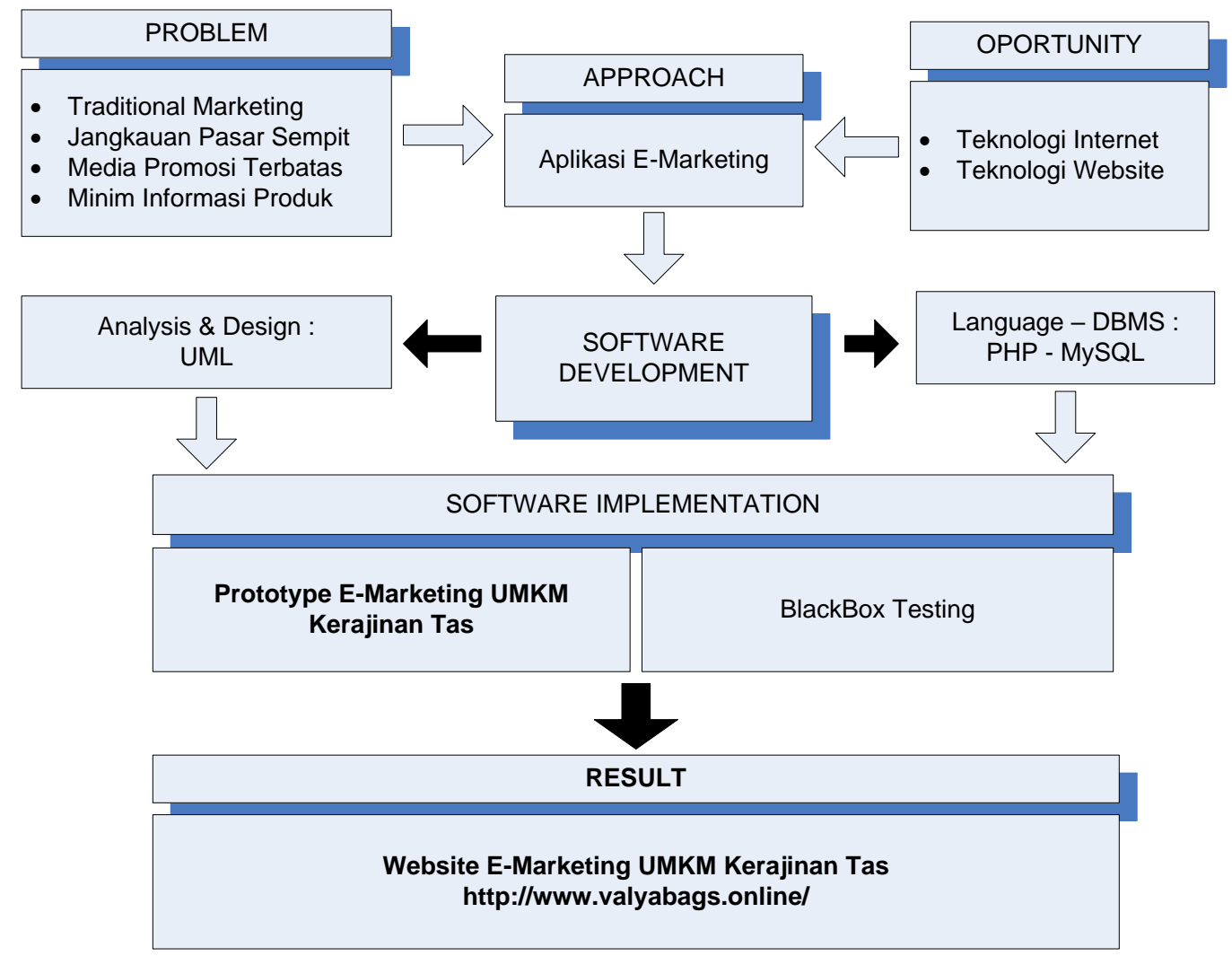

Gambar 1. Kerangka Pikir Penelitian

\section{HASIL DAN PEMBAHASAN}

\subsection{Perancangan Diagram Use Case}

Diagram use case untuk perancangan digital marketing ditunjukan oleh gambar 2. Terdapat dua kator utama yaitu admin sebagai pengelola sistem dan pembeli. Kegiatan proses bisnis digital marketing ini adalah pengelolaan kategori produk, pengelolan pengiriman, melihat informasi katalog produk, proses pemesanan produk, serta konfirmasi pembayaran yang dilakukan oleh pembeli. 


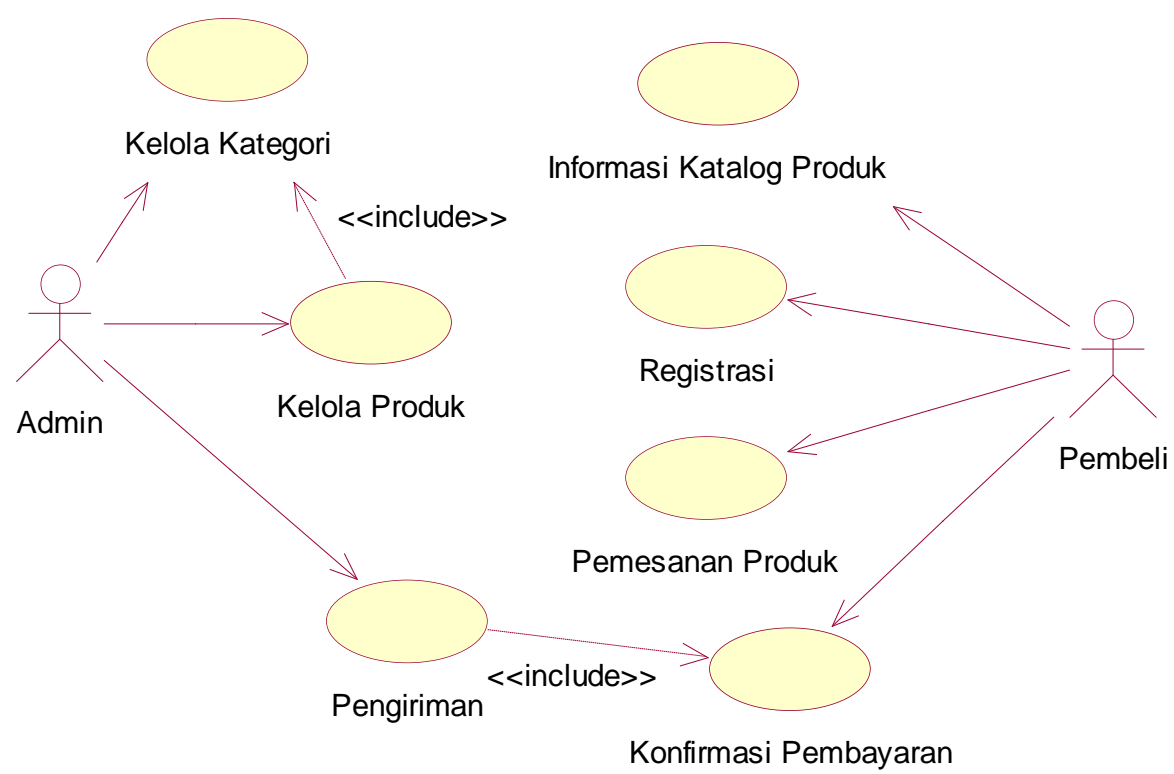

Gambar 2. Diagram Use case Digital Marketing

\subsection{Implementasi Sistem}

a. Halaman Utama

Halaman utama atau tampilan awal $e$ - marketing valyabags.online memiliki menu Home, About, Contact Us dapat dilihat pada gambar 3.

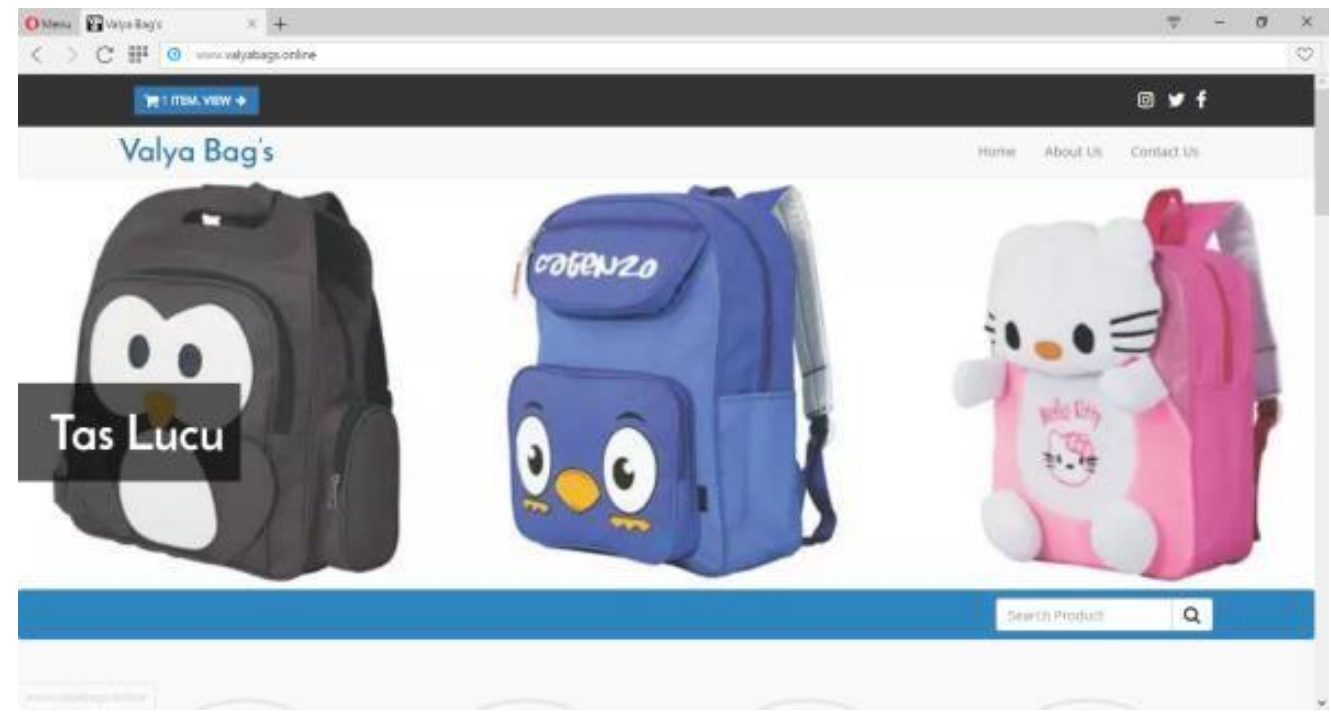

\section{Gambar 3. Halaman Utama Valyabags.online}

b. Halaman Detail Produk

Pada halaman detail produk aplikasi e-marketing memberikan informasi secara detail setiap produk tas. Variabel yang dimunculkan seperti deksripsi produk, harga produk dan pilihan warna yang dapat di pilih oleh pelanggan. halaman detail produk dapat dilihat pada gambar 4 sebagai berikut: 


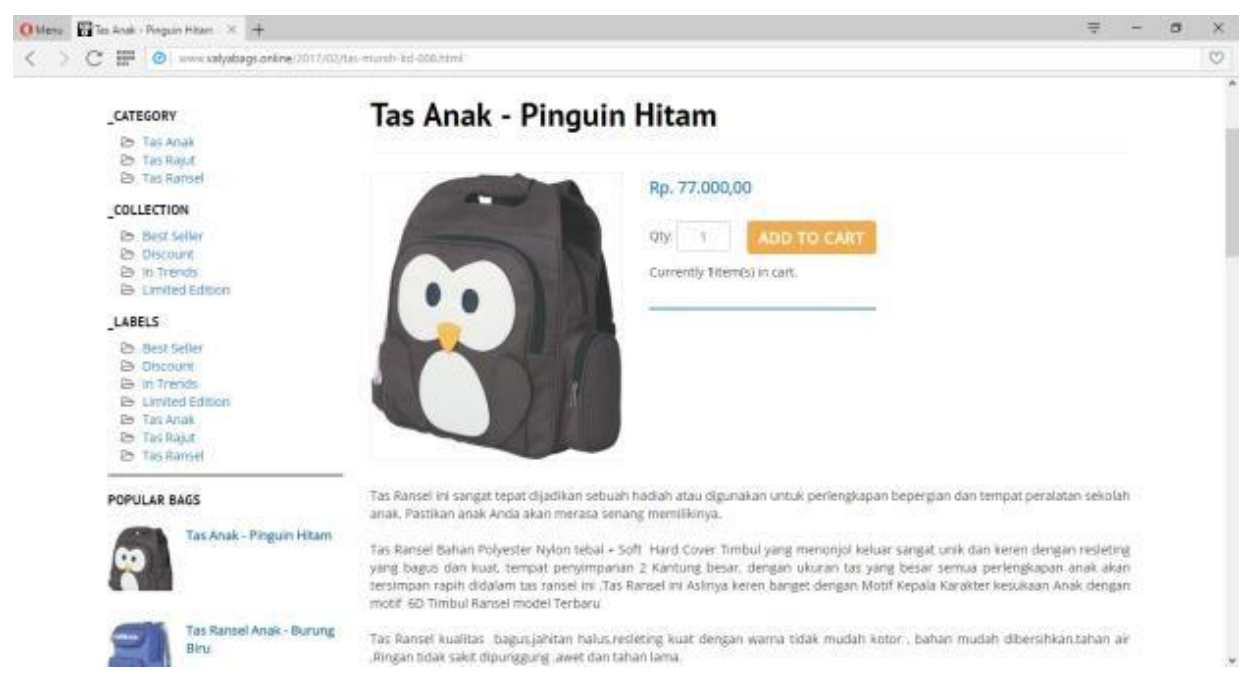

Gambar 4. Tampilan Detail Produk

c. Halaman Pemesanan Produk

Halaman pemesan produk memberikan informasi kepada para pelanggan yang sudah memilih produk yang akan dibeli kemudian memberikan informasi detail harga yang harus dibayarkan oleh pelanggan. Tampilan pemesanan produk dapat dilihat pada gambar 4 sebagai berikut:

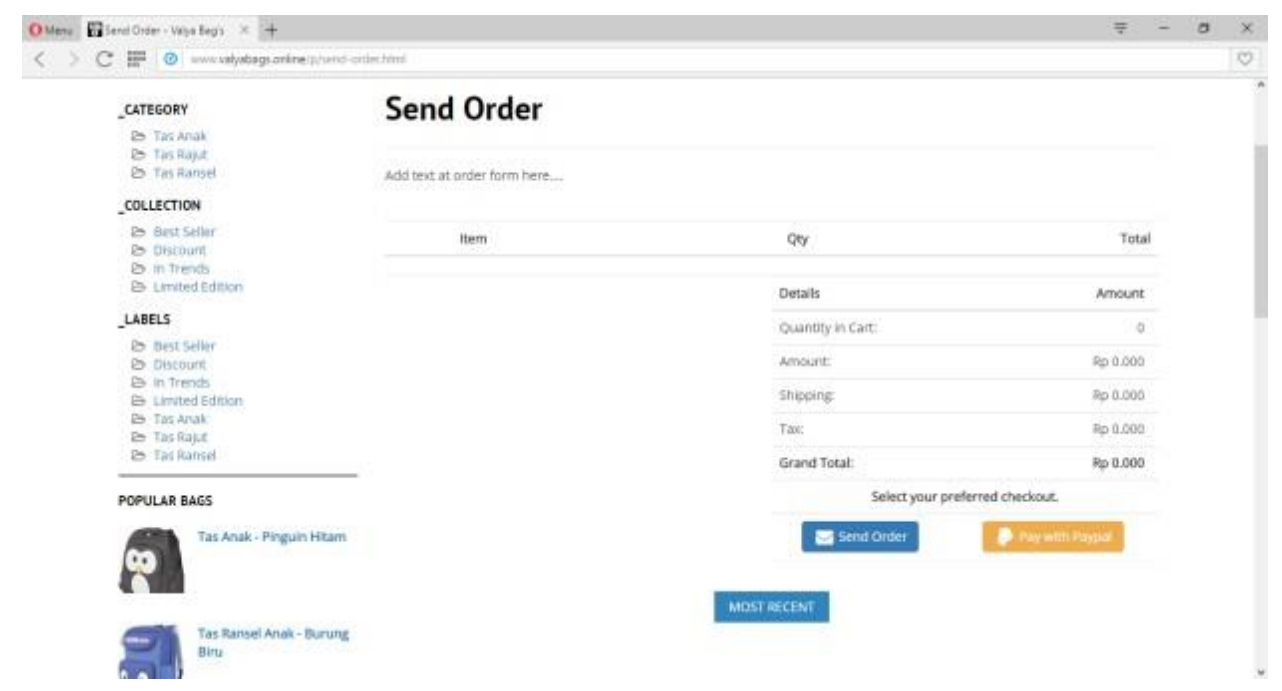

Gambar 4. Halaman Pemesanan Produk

\section{KESIMPULAN}

Berdasarkan analisis dan pembahasan penelitian , maka dapat disimpulkan sebagai berikut:

a. Perancangan e-marketing UMKM mampu menjangkau pasar yang lebih luas, penjual dapat berinteraksi secara langsung dengan pembeli tanpa dibatasi ruang dan waktu. Pembeli lebih banyak dibanding sistem pemasaran secara tradisional yang pada akhirnya dapat meningkatkan perekonomian masyarakat khusunya para pengrajin tas.

b. Implementasi sistem e-marketing UMKM Pengrajin Tas dapat diakses melalui URL http://www.valyabags.online

\section{DAFTAR PUSTAKA}

[1] Santoso, 2015, E-Marketing Pada UKM Sepatu Bunut Abang Adik Kisaran, Jurnal Teknologi dan Sistem Informasi, Vol. 1 No. 2, Maret 2015

[2] Kotler dan Philip, 2004, Dasar-Dasar Pemasaran, Penerbit Erlangga, Jakarta

[3] Budi, S. dkk., 2013, Analisis dan Perancangan Sistem E-Marketing Pada PT Nordic Lift Truck, Journal ComTech Vol. 4 No. 1 
[4] Tanunggal, P., dkk, 2013, Analisis dan Perancangan E-Marketing pada PB. Sami Jaya, Jurnal INFRA Vol. 1 No. 2

[5] Muzdalifah, L., 2017, E-Marketing Sebagai Strategi Pemasaran Untuk Meningkatkan Penjualan di Rumah Pengantin L'Sinta Sidoarjo, Jurnal Penelitian Ilmu Ekonomi WIGA Vol. 7, September 2017

[6] Suhendar, A. dan Gunadi, H., 2002,Visual Modelling Menggunakan UML dan Rational Rose, Informatika, Bandung. 